\title{
PKM PEMBERDAYAAN KELOMPOK PKK DENGAN MODEL URBAN FARMING DI DESA DAWUHAN LOR, KECAMATAN SUKODONO, LUMAJANG, JAWA TIMUR
}

\author{
Nanik Furoidah ${ }^{1 *}$, Muhammad Juhan ${ }^{2 *}$ \\ *Prodi Agroteknologi Fakultas Pertanian, Universitas Islam Jember J1. Kyai Mojo 101 Jember \\ E-mail: nanikfuroidah3@gmail.com¹,muhammadjuhan@yahoo.co.id²
}

\begin{abstract}
ABSTRAK
Laju pertambahan penduduk, urbanisasi, dan alih fungsi lahan pertanian ke non pertanian ber dampak pada banyak aspek kehidupan mulai dari ketahanan pangan, lingkungan, kesehatan, kenyamanan dan suasana yang asri, segar dan alami. Kelompok PKK Desa Dawuhan Lor, Kecamatan Sukodono, Lumajang, Jawa Timur telah berupaya mengatasi dampak tersebut dengan menanam pepohonan dan tanaman hias di tepi jalan depan rumah serta sayuran yang ditanam di halaman rumah dan tempat-tempat yang memungkinkan. Upaya ini dilaksanakan secara sederhana karena keterbatasan pengetahuan dan teknologi di bidang pertanian. Berdasarkan realita tersebut Tim Pengusul Program Kemitraan Masyarakat (PKM) akan membantu mengatasi permasalahan dengan introduksi penerapan model urban farming diantaranya adalah teknologi hidroponik dan inovasi budidaya sayuran, buah, maupun tanaman bumbu secara portabel. Target yang ingin dicapai adalah terwujudnya swadaya $15-25 \%$ kebutuhan sayuran dan bumbu dapur yang digunakan untuk masak sehari-hari serta suasana lingkungan rumah tangga yang lebih asri, alami, segar, sehat dan memberikan kontribusi nyata untuk pemenuhan kebutuhan pangan sehingga dapat mendukung ke arah ketahanan pangan rumah tangga serta menekan pengeluaran belanja untuk membeli sayuran dan bumbu. Metode pendekatan dilaksanakan melalui pendidikan dan pelatihan soft skill, penyuluhan dan tutorial dimaksudkan untuk membuka wawasan dan pengetahuan tentang urban farming; pelatihan skill tentang dasar-dasar urban farming; dan pembentukan kader ketahanan pangan keluarga.
\end{abstract}

Kata kunci: pemberdayaan, urban farming, ketahanan pangan

\section{PENDAHULUAN}

\section{Analisis Situasi}

Fluktuasi harga komoditas sayuran yang sangat tajam, masih segar dalam ingatan kita dalam dua tahun terakhir dimana komoditas cabe merah dan cabe rawit sering mengalami gejolak harga yang berakibat pada keresahan masyarakat begitu juga pada harga komoditas tomat, bawang merah dan bawang putih. Padahal tanaman-tanaman tersebut secara teknis mudah dibudidayakan di pekarangan maupun di halaman sempit yang dimiliki rumah-tangga khususnya di daerah perkotaan.

Menurut Kementerian Pertanian (2011), penataan pekarangan ditujukan untuk memperoleh manfaat yang sebesar-besarnya melalui pengelolaan lahan pekarangan secara intensif dengan tata letak sesuai dengan pemilihan komoditas. Pemilihan komoditas ditentukan dengan mempertimbangkan pemenuhan kebutuhan pangan dan gizi keluarga, diversifikasi pangan berbasis sumberdaya lokal, serta kemungkinan pengembangannya secara komersial berbasis kawasan. Komoditas yang dapat dikembangkan antara lain: sayuran, tanaman rempah dan obat, buah yang disesuaikan dengan lokasi setempat serta berbagai sumber pangan lokal (ubi jalar, ubi kayu, ganyong, talas). Menurut Thomaier, S, et al. (2014) bahwa daerah perkotaan harus menjadi tempat hunian bagi penduduknya serta menawarkan kesempatan sosial ekonomi.
Pertambahan penduduk, pertumbuhan ekonomi, urbanisasi, dan industrialisasi merupakan fenomena yang terjadi di kotakota besar dan juga kota-kota tingkat kabupaten/kota. Dampak dari fenomena tersebut di antaranya adalah beralihnya fungsi tanah yang semula lahan produktif untuk pertanian menjadi lahan industri, aktivitas ekonomi, perkantoran, perumahan, jalan raya, dan sarana prasarana umum lainnya. Laju alih fungsi lahan tersebut secara nasional sangat mengkhawatirkan yaitu mencapai 100 ribu hektar per tahun sementara laju pencetakan lahan baru masih 40 ribu hektar per tahun (Anonim, 2014). Hal ini juga terjadi juga terjadi di Kabupaten Lumajang pada tiga tahun terakhir yaitu mulai tahun 2014-2016 sebagaimana ditunjukkan pada tabel 1 .

Tabel 1. Alih Fungsi Lahan Sawah di Kabupaten Lumajang Tahun 2014-2016

\begin{tabular}{|c|c|c|c|c|}
\hline No & Tahun & $\begin{array}{c}\text { Permohonan } \\
\text { (ha) }\end{array}$ & $\begin{array}{c}\text { Diterima } \\
\text { (ha) }\end{array}$ & $\begin{array}{c}\text { Ditolak } \\
\text { (ha) }\end{array}$ \\
\hline 1 & 2014 & 18,693 & 6,493 & 12,200 \\
\hline 2 & 2015 & 22,842 & 10,942 & 12,200 \\
\hline 3 & 2016 & 7,604 & 2,904 & 4,700 \\
\hline \multicolumn{2}{|c|}{ Jumlah } & 49,139 & 20,339 & 28,800 \\
\hline
\end{tabular}

Sumber: Pusdatin.setjen.pertanian.go.id (2016). 
Realita di lapangan banyak hunian di komplek perumahan maupun perkampungan yang mempunyai pekarangan atau halaman rumah yang kurang luas bahkan sempit/terbatas. Selain itu pertambahan jumlah penduduk berkorelasi positif dengan makin meningkatnya kebutuhan bahan makanan sebagai sumber nutrisi dan gizi masyarakat, baik berupa tanaman pangan, maupun hortikultura yang bersifat perisabel (produk segar dan mudah rusak). Belum lagi fluktuasi harga pangan terutama komoditas sayuran yang sangat tajam akan sangat berpengaruh pada pengeluaran belanja rumah tangga serta menambah kompleksitas masalah yang dihadapi masyarakat perkotaan. Dampak lainnya adalah semakin sulitnya menghadirkan lahan untuk berkebun, suasana segar, sehat, asri, nyaman dan alami di lingkungan rumah tangga, serta pasokan untuk memenuhi kebutuhan pangan hampir semuanya bertumpu dari kawasan pedesaan.

Umumnya para ibu di lingkungan perumahan lebih senang menyalurkan hobi berkebunnya dengan menanam berbagai macam tanaman hias baik yang berbunga maupun berdaun indah di dalam pot yang diletakkan di tepi jalan luar pagar rumahnya, yang berfungsi untuk estetika maupun menciptakan suasana asri dan nyaman. Bentuk pemberdayaan ibu-ibu rumah tangga pada kelompok PKK akan sangat efektif dan efisien dengan memberikan motivasi dan pembelajaran langsung praktek tentang bagaimana mengoptimalkan terbatasnya ruang halaman yang ada menjadi berdaya dan mempunyai nilai manfaat lebih untuk keluarga melalui penerapan sistem bercocok tanam secara semi konvensional (menggunakan polybag/plastic recycle) dan non konvensional (hidroponik).

Pemberdayaan para ibu rumah tangga yang tidak bekerja di luar rumah untuk menjadi lebih produktif dengan kegiatan berkebun tanaman sayuran merupakan solusi yang tepat pada hunian perumahan maupun perkampungan, minimal dapat mengurangi pengeluaran anggaran belanja sehari-hari terutama untuk pembelian sayuran maupun bumbu dapur. Keterbatasan lahan untuk bercocok tanam, kurangnya pengetahuan teknik bercocok tanam adalah masalah utama yang umum dijumpai di komplek-komplek perumahan, meskipun demikian beberapa di antara warganya tetap bercocok tanam karena merupakan hobi atau sekedar untuk memenuhi sebagian kecil kebutuhan pangan sehari-hari, kondisi seperti inilah yang ada di lokasi sasaran. Berdasarkan daftar anggota ibu-ibu PKK yang ada di RT 45 dan 46 Perumahan Bumi Moro, Desa Dawuhan Lor, Kecamatan Sukodono, Kabupaten Lumajang ada 19 orang (54\%) sebagai Ibu Rumah Tangga dan 16 orang (46\%) bekerja sebagai Pegawai Negeri Sipil, Karyawan Swasta atau berwirausaha. Kegiatan rutin di antaranya adalah arisan PKK, Bank Sampah, pemanfaatan halaman (ruang terbuka) untuk aktivitas bercocok tanam terutama sayuran dan kegiatan-kegiatan temporer seperti demo masak dan ketrampilan. Kegiatan bercocok tanam yang telah dilaksanakan selama ini sudah cukup baik namun masih perlu sentuhan teknologi dan pengetahuan tepat guna untuk meningkatkan peran dan produktifitas kegiatan tersebut, antara lain dengan pembekalan ilmu dan teknologi bidang pertanian.

Keterbatasan lahan untuk bercocok tanam di wilayah perkotaan terutama pada hunian komplek perumahan maupun perkampungan perlu mendapatkan solusi yang mudah, murah dan terjangkau pelaksanaannya, antara lain dengan memperkenalkan konsep urban farming (UF) kepada masyarakat terutama warga yang tinggal di perkotaan dan komplek perumahan.

\section{Permasalahan Mitra}

Masalah utama yang dihadapi oleh para ibu rumah tangga di perkotaan pada umumnya adalah:

1. Ketergantungan bahan pangan dari daerah pedesaan sangat tinggi, hal ini perlu dikurangi dan diutamakan pada komoditas yang mempunyai nilai tinggi serta hampir dibutuhkan setiap hari.

2. Terbatasnya lahan untuk bercocok tanam, maka perlu dicarikan alternatif cara bercocok tanam yang memungkinkan untuk memanfaatkan lahan sempit atau area dirumah sehingga dapat mengeliminir masalah keterbatasan lahan yang dihadapi.

3. Pada umumnya pengetahuan dan ketrampilan bercocok tanam yang dimiliki oleh para ibu rumah tangga masih perlu ditingkatkan. Dalam mengatasi masalah mitra sebagaimana tersebut di atas, maka pengusul bersama mitra diwakili oleh ibu ketua RT 45 dan 46 bersepakat melakukan pemberdayaan ibu-ibu rumah tangga di kedua RT tersebut dengan kegiatan bercocok tanam secara semi konvensional yaitu dengan menggunakan polybag atau recycle sampah plastik; serta cara budidaya tanaman secara non konvensional dengan teknik hidroponik. Jenis tanaman yang diusahakan merupakan tanaman hortikultur baik dari jenis tanaman sayur, buah maupun pelengkap bumbu dapur seperti: cabe, tomat dan rimpang-rimpangan.

\section{Solusi}

Masalah yang dihadapi mitra ibu-ibu rumah tangga di RT 45 dan RT 46 Perumahan Bumimoro, Desa Dawuhan Lor, Kecamatan Sukodono, Kabupaten Lumajang perlu dicarikan solusi antara lain dengan:

1. Pendekatan persuasif terhadap mitra dalam rangka memberikan motivasi dan pengetahuan tentang bercocok tanam pada lahan terbatas dengan kegiatan penyuluhan tentang Urban farming. Adapun target luaran pada mitra diharapkan $80 \%$ dari peserta latihan mampu memahami tentang: 1. Pengertian dan model-model urban farming; 2. Pengertian dan kegunaan unsur hara bagi tanaman; 3 . Cara sederhana meracik nutrisi tanaman; 4. Perawatan dan 
pemeliharaan tanaman. Target tersebut dapat ditunjukkan pada kemampuan menjawab pertanyaan yang diberikan minimal $70 \%$ jawaban benar.

2. Kegiatan pelatihan teknik dan metoda urban farming, yaitu: metode semi konvensional dan non konvensional. Adapun target luaran pada mitra diharapkan $80 \%$ dari peserta latihan mampu memahami dan memperagakan tentang: 1. Penyiapan peralatan dan bahan yang diperlukan; 2. Cara bercocok tanam semi konvensional dan non konvensional. Target tersebut dapat ditunjukkan pada kemampuan memperagakan minimal $70 \%$ benar.

3. Kegiatan pelatihan teknik dan metode pengendalian hama dan penyakit. Target yang ingin dicapai $80 \%$ dari peserta latihan mampu memahami dan memperagakan tentang: 1. Deteksi tentang hama dan penyakit tanaman; 2. Cara pengendalian dan pemberantasan hama dan penyakit tanaman. Target tersebut dapat ditunjukkan dengan kemampuan menjelaskan dan mempraktikkan minimal $70 \%$ benar.

4. Pembentukan kader ketahanan pangan rumah tangga/ keluarga. Target yang diharapkan 2-3 orang peserta ditunjuk oleh peserta sebagai pengurus kelompok untuk keberlanjutan kegiatan urban farming di masingmasing lokasi. Adapun target secara keseluruhan dari beberapa solusi kegiatan yang ditawarkan adalah terwujudnya swadaya 15-25\% kebutuhan sayuran dan bumbu dapur yang digunakan untuk masak sehari-hari dapat memberikan kontribusi nyata untuk pemenuhan kebutuhan pangan sehingga dapat mendukung ke arah ketahanan pangan rumah tangga serta menekan pengeluaran untuk membeli sayuran dan bumbu, serta terciptanya suasana lingkungan rumah tangga yang lebih asri, alami, segar, sehat.

\section{METODE PELAKSANAAN}

Langkah yang dibutuhkan untuk menyelesaikan permasalahan yang telah diungkapkan adalah dengan menciptakan model urban farming (pertanian kota) yang mudah, murah dan terjangkau oleh masyarakat, antara lain dengan:

1. Pendidikan dan pelatihan soft skill, dimaksudkan untuk membuka wawasan dan pengetahuan tentang urban farming antara lain meliputi: syarat tumbuh, media tanam, pengenalan macam-macam pupuk dan pemupukan, mengidentifikasi hama dan penyakit serta upaya pengendaliannya, manajemen pemeliharaan tanaman. Untuk kegiatan ini dilakukan melalui ceramah dan diskusi dengan mendatangkan nara sumber yang kompeten di bidangnya dan melibatkan aparat kelurahan setempat. Peserta seminar meliputi perwakilan ibu-ibu dari Perumahan Bumimoro RT 45 dan RT 46, Desa
Dawuhan Lor, Kecamatan Sukodono, Kabupaten Lumajang, dengan jumlah peserta sekitar 25 - 30 orang.

2. Pelatihan skill, dimaksudkan untuk memberikan bekal ketrampilan dasar-dasar urban farming. Peserta dibagi menjadi kelompok-kelompok yang terdiri dari $4-5$ orang setiap kelompok. Masing-masing kelompok akan diberi tugas untuk kepentingan bersama, misalnya kelompok 1 diberi tugas pembibitan cabe rawit, kelompok 2 pembibitan tomat, dan seterusnya sehingga masingmasing kelompok mempunyai tanggung-jawab serta ada semangat kompetisi yang bersifat konstruktif. Selanjutnya dilakukan penanaman model, sebagai berikut:

a. Pertanian semi konvensional merupakan model pertanian modifikasi dari sistem konvensional dengan cara menanam tanaman dalam polybag (wadah) yang diisi dengan media tanam (campuran tanah, pupuk kandang, dan sekam padi) dan dikelola secara intensif. Pertanian non konvensional merupakan model pertanian yang menggunakan media tanam selain tanah sehingga memberi kesan lebih bersih dan relatif lebih hemat terhadap kebutuhan ruang, praktis dan efisien.

3. Pembentukan Kader Ketahanan Pangan Keluarga, dimaksudkan untuk memudahkan komunikasi baik dalam internal kelompok maupun antara kelompok dengan tim pelaksana PKM serta memperoleh akses yang terkait dengan pengembangan kelompok, nantinya diharapkan dapat menjadi inisiator pengembangan urban farming. Nutrisi tanaman, pupuk dan pemupukan; Media tanam, pembibitan, dan penanaman; Pemeliharaan tanaman dan pengendalian hama dan penyakit; Panen dan penanganan pasca panen.

5. Pelaksanaan, dalam pelaksanaan kegiatan ini meliputi:

a. Penyampaian materi teknik bercocok tanam, keunggulan dan kelemahan pertanian semi konvensional dan non konvensional, sesuai modul pelatihan.

b. Pelatihan/demo teknik bercocok tanam, setiap peserta diberi bahan untuk mempraktekkan sendiri pada kelompok masing-masing dan dipantau tim pelaksana.

c. Monitoring dan Evaluasi, dilakukan pada pra-pelaksanaan, pelaksanaan dan pasca pelaksanaan. Hal ini dimaksudkan untuk mengetahui tingkat pengetahuan dan ketrampilan, penerimaan materi, keberhasilan, semangat dan antusias peserta.

\section{PEMBAHASAN}

\section{Pendidikan dan Pelatihan Soft Skill}

Kegiatan pendidikan dan pelatihan soft skill berhasil membuka wawasan dan pengetahuan tentang urban farming 
melalui sosialisasi dengan cara mengisi kuesioner serta ceramah tentang syarat tumbuh, media tanam, pengenalan macam-macam pupuk dan pemupukan, mengidentifikasi hama dan penyakit serta upaya pengendaliannya, manajemen pemeliharaan tanaman. Sebagian besar ibu PKK RT 45 dan 46 antusias dan termotivasi serta $80 \%$ memberikan respons dengan hasil sangat positif. Stimulasi dengan pemberian paket hidroponik wick system, benih sayur selada, sawi, bibit tanaman buah jambu air MDS, stroberi dapat memotivasi dan mendorong ibu-ibu kelompok PKK untuk melakukan budidaya tanaman tanpa media tanah maupun dengan tanah secara portabel. Sisi lain dari budidaya secara hidroponik maupun portabel adalah dapat mempermudah kegiatan bercocok tanam, selain juga menghasilkan kebutuhan pangan keluarga sekaligus mengurangi anggaran belanja dan menambah estetika lingkungan rumah.

\section{Pelatihan Skill}

Kegiatan pelatihan skill mampu meningkatkan ketrampilan kelompok PKK lebih kurang 70\% baik terampil bercocok tanam secara konvensional maupun semi konvensional dengan hidroponik maupun portabel, meskipun ada sebagian kecil yang belum dapat berhasil melakukan budidaya hidroponik seperti yang diharapkan. Salah satu kelemahan yang dikeluhkan adalah waktu proses pembibitan sayur sawi, selada hidroponik lebih kurang 10-14 hari pada media rockwool, membutuhkan pemeliharaan terhadap kelembaban dan intensitas cahaya, sedangkan untuk pembibitan konvensional cukup disemai di media tanah dan pasir. Kelemahan ini justru meningkatkan animo para ibu kelompok PKK untuk berbudidaya stroberi melalui perbanyakan vegetatif menggunakan stolon. Pembibitan lebih cepat dan mudah dengan media tanah, serta pada umur 3 bulan sudah berbuah dan siap petik.

\section{Kader Ketahanan Pangan Keluarga}

Langkah pemberdayaan kelompok PKK di Desa Dawuhan Lor, Kecamatan Sukodono, Lumajang dengan kegiatan urban farming mampu menyumbang 15-20\% kebutuhan sayur, bumbu alami, maupun buah dari pekarangan rumah sendiri. Terbentuknya kader ketahanan pangan keluarga di setiap RT menjadi sangat efektif dalam menjalin komunikasi dengan tim pelaksana sekaligus menjadi inisiator keberlanjutan urban farming. Peran kader adalah mengkoordinasi kegiatan urban farming di setiap RT, seperti membagikan bibit stroberi hasil perbanyakan vegetatif(dengan stolon) kepada kelompok PKK lain. Dengan bekal soft skill dan pelatihan yang diberikan oleh nara sumber dan tim pelaksana kader diberi tugas lain untuk saling berbagi pengalaman baik dalam pemeliharaan tanaman, cara perbanyakan, dan lainnya. Tim pelaksana juga melakukan komunikasi intensif, monitoring serta evaluasi kegiatan di lingkungan tersebut. Monitoring dilakukan hampir setiap minggu disertai dengan kegiatan dokumentasi sebagai bukti kegiatan telah dilakukan sekaligus meningkatkan semangat para kelompok PKK untuk senantiasa aktif melakukan pemeliharaan terhadap tanaman yang telah dibudidayakan (menyiram, memupuk, dll). Terbentuknya kader ketahanan pangan keluarga ini juga mempunyai peran dan kontribusi dalam peningkatan kualitas lingkungan, serta konsolidasi yang baik antar kelompok PKK, sehingga mempermudah komunikasi antar warga, dan yang tidak kalah penting semangat para ibu PKK dalam mengoptimalkan fungsi pekarangan maupun memaksimalkan fungsi ruang terbuka yang ada dengan tanaman hortikultur dapat memenuhi kebutuhan gizi keluarga secara aman dan lebih higienis.

Berdasarkan hasil monitoring dan evaluasi, tim pelaksana memandang perlu upaya sosialisasi yang lebih efektif, lebih luas dengan target bahwa para ibu kelompok PKK di Desa Dawuhan Lor dapat lebih meningkatkan ketrampilan budidaya hidroponik dengan lebih baik. Upaya yang digagas tim pelaksana untuk peningkatan ketrampilan hidroponik kelompok Ibu-Ibu PPK adalah sosialisasi yang dikemas dalam bentuk "Lomba Hidroponik Sayuran dan Buah Semusim".

\section{KESIMPULAN DAN SARAN}

Berdasarkan kegiatan yang telah dilaksanakan di Desa Dawuhan Lor, Lumajang, dapat disimpulkan bahwa.

1). Pemberdayaan kelompok PKK terhadap kegiatan urban farming di Desa Dawuhan Lor telah berhasil dicapai; 2). Kegiatan urban farming memberi sumbangsih dalam pemenuhan gizi keluarga; 3 ). Terbentuknya kader ketahanan pangan keluarga sangat efektif sebagai inisiator berlangsungnya urban farming secara berkelanjutan 3). Kendala sementara adalah pembibitan sayuran secara hidroponik dengan media rockwool.

\section{UCAPAN TERIMA KASIH}

Tim pelaksana menyampaikan banyak terima kasih kepada Direktorat Riset dan Pengabdian pada Masyarakat, Kementerian Riset, Teknologi, dan Pendidikan Tinggi yang telah mendanai kegiatan ini.

\section{DAFTAR PUSTAKA}

Adjaye, P, A. 2012. The Tendency to Urban-Farm in Accra: A Cultural Lag-Labor Surplus Nexus. Journal of Third World Studies: Fall 2012;29,2; Technology Collection.

Anonim, 2014. Tempo.co. Malang. 
Anonim, 2016. Pusat Data Informasi Sekretaris Jendral Pertanian. Dinas Pertanian Lumajang. http:// pusdatin.setjen.pertanian.go.id/tinymcpuk/g ambar/ file/Dari\%20Lumajang\%20untuk\%20Indo nesia_ distanlumajang2016.pdf

Dimitri, C, et al. 2016. Urban Agriculture: Connecting Producers with Consumers. British Food Journal. Vol. 118, No.3, pp: 603-617. Emerald Group Publishing Limited.

Kementerian Pertanian. 2011. Pedoman Umum Model Kawasan Rumah Pangan Lestari (M-KRPL). Kementerian Pertanian, Jakarta.
Mengual, E, S, et al. 2015. Resolving Differing Stakeholder Perceptions of Urban Rooftop Farming in Mediterranean Cities: Promoting Food Production As a Driver for Innovative Forms of Urban Agriculture. Agric Hum Values (2016) 33:101-120.

Thomaier, S, et al. 2014. Farming in and on Urban Buildings: Present Practice and Specific Novelties of Zero-Acreage Farming (ZFarming). Renewable Agriculture and Food Systems: 30 (1); 43-54. 